\title{
Personnel Evaluation and the Military Manager: Contrasts in Performance Appraisal Systems
}

John P. Pelissero

Loyola University Chicago, jpeliss@luc.edu

Follow this and additional works at: https://ecommons.luc.edu/politicalscience_facpubs

Part of the Political Science Commons

\section{Recommended Citation}

Pelissero, John P., "Personnel Evaluation and the Military Manager: Contrasts in Performance Appraisal Systems," Public Personnel Management 13 (Summer 1984): 121-132.

This Article is brought to you for free and open access by the Faculty Publications and Other Works by Department at Loyola eCommons. It has been accepted for inclusion in Political Science: Faculty Publications and Other Works by an authorized administrator of Loyola eCommons. For more information, please contact ecommons@luc.edu. (c) 1 () $\Theta$

This work is licensed under a Creative Commons Attribution-Noncommercial-No Derivative Works 3.0 License. 


\title{
Personnel Evaluation and the Military Manager: Contrasts in Performance Appraisal Systems
}

\author{
by
}

John P. Pelissero

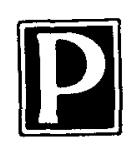

erformance appraisal is a key element of personnel management in the public sector. Recent changes in the process of evaluating public employees have given way to different emphases in appraisal systems. The most widely publicized change in the public sector has been the implementation of the Civil Service Reform Act of 1978 which established a new performance appraisal system for federal civilian employees (see, for example, Sugar, et al., 1979; Thayer, 1981; Thompson, 1981; Brown, 1982; Sherwood, 1982-83; DeMarco and Nigro, 1983). Perhaps not as well publicized outside of the Department of Defense were new evaluation systems for commissioned officers and enlisted personnel in the Department of the Army. A new Officer Evaluation Reporting System was implemented by the Army in September 1979 (Department of the Army, 1979). A modification of the Enlisted Evaluation Reporting System was released for use in October 1981 (Department of the Army, 1981a). Like the modifications of the Civilian Performance Appraisal System that were implemented in 1980-81, each of the military personnel systems attempted to improve the quality and usefulness of officer and enlisted evaluations.

One of the by-products of these reforms has been to create three divergent systems containing different approaches to management and establishing somewhat different standards for appraisal among systems. This has put the Army manager in the position of having to understand and implement three policies that do not share common approaches or values in the personnel management area. It is quite possible for a manager to have both military and civilian personnel performing virtually identical duties, while each is managed, for appraisal purposes, in quite different ways. This paper compares the three systems on several dimensions to highlight some of these contrasts. One is the role of performance objectives planning in the process of conducting evaluations on officers, enlisted personnel, and civilians. Second, the paper

John P. Pelissero is an Assistant Professor of Political Science at Texas A\&M University. His teaching areas include public administration theory, public personnel management, policy evaluation, and urban politics. He is the author of several monographs, including Recruitment and Selection Practices in Oklahoma Police Departments. Articles of his have appeared in Public Administration Review, American Political Science Review, The Journal of Politics, and in other journals and books. He is a former Army personnel officer. 
compares the systems on explicit and implicit use of trait evaluation components that are either high or low in job-relatedness. The third area of inquiry focuses on objective versus subjective components of these systems. Finally, the systems are examined for reliance upon a numerically scored rating system.

\section{PERFORMANCE STANDARDS AND OBJECTIVES}

Both the Officer Evaluation Reporting System (OERS) and the Civilian Performance Appraisal System (CPAS) have been touted as new innovations in the application of management-by-objectives concepts to public employee management. No such claims have been made in the development of the new Enlisted Evaluation Reporting System (EERS) and the lack of any objectives planning between managers and enlisted personnel is noticeable in that system. An explanation of each system's development and implementation might be worthwhile here.

The first "new" system to confront Army managers, both civilian and military, was OERS. Previous officer evaluation policies did not contain performance planning and goal-setting. In addition, if a "goal" was present under former policies, it was the achievement of a maximum score (200) on the evaluation. That score and its resultant inflation in the rendering of evaluations probably led to reform of OERS more than any other deficiency. The 1979 reform places an objectives planning process at the heart of the appraisal. The rated officer, with guidance from the rating supervisor, completes an Officer Evaluation Report "Support Form" at the start of the evaluation period. Specific duties and responsibilities are listed on the form along with a set of performance objectives that relate to these responsibilities. This support document is kept available to both rater and ratee throughout the evaluation period for review and revision. A key expectation is that the rating manager will assist the rated individual in developing a course of action that will facilitate goal accomplishment. At the end of the rating period, normally 12 months, the rated individual must list what he/she has accomplished during the rating period. This is done by completing the support form with specific areas of success in accomplishing stated objectives.

Table 1 shows that in OERS the ratee is expected to establish both individual and organizational objectives at the start of the rating period. These may include any of four types of objectives: routine, problem-solving, innovative, or personal development (Department of the Army, 1981b, p. 4-4). This forces an officer to plan ahead and it allows, through the use of organizational objectives, a rated individual to assist the rating manager in the process of managing the organization's direction. Both organizational and individual performance objectives are explicit in the development of the OER support form. This list of significant contributions is then used in evaluation of the officer's performance during the rating period. As planned, OERS is a "management-by-objectives" program (Stevens, 1980).

The Civilian Performance Appraisal System has also been touted as a "management-by-objectives" system (Sugar, 1979; Thompson, 1981; Colvard, 1982-83). The Civl Service Reform Act required agencies to develop appraisal methods that ". . .encourage employee participation in establishing performance objectives. . ." The "Job 
TABLE 1

Relative Use of Performance Objectives and Performance Standards In Army Military and Civilian Personnel Performance Appraisals

\begin{tabular}{cccc}
\hline Type & OERS & EERS & CPAS \\
\hline Performance Objectives Planning: & & & \\
Organizational Objectives & E & & \\
Individual Objectives & E & & I \\
Performance Standards & $\mathrm{I}$ & & $\mathrm{E}$ \\
Established & & & \\
\hline
\end{tabular}

Notes: E - Explicit component of appraisal

I - Implicit part of appraisal

Performance Planning Worksheet" is a listing of explicit performance standards by which the employee will be evaluated throughout the rating period (see Table 1). As intended, the performance plan is developed by both manager and employee. It contains a list of "major job elements," the "critical" nature of each" ${ }^{2}$, related "supporting tasks," and most importantly, performance standards ${ }^{3}$ for each job element/task. Employees can be especially useful in planning this document as they identify the major job elements and supporting tasks of their position. In essence, this list and its accompanying performance standards, form the "performance contract" between manager and employee that will be used during the rating period. The plan, which may be modified during the period to reflect changing job requirements, tasks, or needed modifications of standards, is signed by both the rating manager and the employee. By this means an employee gains a written list of standards which he/she must meet to be rated successful at the end of the rating period. Implicitly, this is a compilation of organizational objectives which the individual must assist in attaining through individual task accomplishment.

Individual objectives planning is implicit in the system, although its particular location in the Department of the Army implementation of CPAS is perhaps awkward. At the time of the performance appraisal the supervisor and employee jointly prepare an "Individual Development Plan" (IDP) for the employee. This plan is to cover the forthcoming rating period and includes plans for training, development assignments, and a list of self-development activities that the employee plans to pursue during this period. Supervisors have the additional requirement to report on the status of the previous IDP, particularly in terms of IDP accomplishment. All of this means that the current year's IDP is only found in last year's performance appraisal - which must be dug out at performance appraisal time to refresh everyone's memory on what was planned. To the outsider this may not appear to be a problem. But to rating managers it is an awkward system since all other portions of the current rating period "plan" are contained in the Job Performance Planning Worksheet. Unfortunately, the individual development plan gets lost in the process since it is not contained in this document which really serves as the true basis for evaluation. 
The third army evaluation system, for senior enlisted soldiers, or grades E5 (Sergeant/Specialist 5) through E9 (Sergeant Major), is the Enlisted Evaluation Reporting System. Formerly the Army operated with two levels of enlisted evaluation, one for senior enlisted personnel (grades E6 to E9), similar to that discussed here, and another for junior enlisted personnel in grades E4 and E5. The current EERS was begun in late 1981 and was designed to produce better evaluations of enlisted personnel who, in many instances, are first- or second-line supervisors of both military and civilian employees. As can be assumed from the information in Table 1, EERS makes no claim to being a management-by-objectives program. At no point during the evaluation period is a rating manager required to discuss performance objectives with the rated individual and it is unlikely that many do. In addition, unlike CPAS, EERS policy does not require any pre-appraisal discussion of performance standards. Many enlisted personnel, therefore, may proceed through the evaluation period with no knowledge of what objectives their rater would like to see them accomplish, and often with no idea of standards of evaluation to be used by the rater. Of course, this information may surface in discussions that are conducted between rater and employee at various times during the period. But what is interesting here is that, unlike the system for both officers and civilians, enlisted personnel do not have objectives or performance standards formalized in written documents which could serve as a guide for personal objectives during the rating period. Many enlisted personnel may be serving alongside civilian employees who perform identical duties but are guided by performance standards. Also, enlisted personnel discharge many of the same supervisory responsibilities as officers and civilians: acting as first- or second-line supervisor, counseling subordinates, training employees, overseeing task accomplishment in an agency/office/shop/field setting, or rating civilians (using CPAS) and other enlisted personnel. Somehow the similarity in jobs has escaped Army planners in the development of its appraisal systems. This factor, along with others to be discussed below, suggests that EERS is a less mature evaluation system than that used for officers and civilians. "Theory X" (McGregor, 1960) appears to be alive and well in EERS. McGregor (1972) specifically called for the abandonment of this type of performance appraisal in favor of one that might resemble OERS or CPAS:

A sounder approach, which places the major responsibility on the subordinate for establishing performance goals and appraising progress toward them, avoids the major weaknesses of the old plan and benefits the organization by stimulating the development of the subordinate. It is true that more managerial skill and the investment of a considerable amount of time are required, but the greater motivation and the more effective development of subordinates can justify these added costs (1972: 138).

\section{JOB-RELATEDNESS OF EVALUATION COMPONENTS}

A useful way to compare the appraisal systems is in terms of the standards or values that are rated. Nalbandian (1981) developed a matrix of job-related expecta- 
tions that were classified into high and low on job-relatedness and further grouped according to whether an expectation is explicitly or implicity called for in the appraisal. His matrix classifies items that appraise the quantity, quality, or timeliness of work as high job-related factors, normally explicitly evaluated. Other high jobrelated items, often only implicitly included in an evaluation, are such behavior characteristics as loyalty, group skills, and individual values. On the low side of jobrelatedness, Nalbandian would classify such items aś dress code compliance, hair length, age, and lifestyle (pp. 392-393).

Table 2 summarizes trait evaluation components of OERS, EERS, and CPAS. Following Nalbandian's dichotomy, the items are categorized by high or low job-relatedness. The components are then coded by the locus of evaluation in the systems explicit or implicit. A few items coded for CPAS are task specific, that is, if a task is specifically included in an individual's performance standards, then an explicit evaluation of the component is demanded. If not included as a task, that component will be neither explicitly nor implicitly evaluated.

A simple observation from the information in Table 2, is that OERS and EERS rely much more on trait evaluation components than does CPAS. Another is that OERS includes more explicit traits which can be evaluated than does EERS. There are 20 specific high job-related items that must be evaluated by OERS raters. Formally, these are classified as either "professional competence" or "professional ethics" traits. The competence factors include task knowledge, development and motivation of subordinates, written and oral communication abilities, judgment, adaptability, performance under stress, conceptual capacity, self-improvement, setting high standards, and supporting equal opportunity programs. Included among the list of professional ethics traits are dedication, responsibility, loyalty, discipline, integrity, moral courage, and selflessness.

EERS requires objective evaluation of many of the same traits that are included in OERS. Army managers must rate enlisted personnel on such traits as task-related technical skills, development of subordinates, communication ability, judgment, performance under stress, adaptability, self-improvement, loyalty, discipline, integrity, moral courage and support for equal opportunity policy. One trait included here, but not in OERS, is initiative. Perhaps interesting to note as a further contrast between these two military systems, enlisted personnel are not rated on several explicit traits found in OERS: establishing high standards, dedication, responsibility, encouraging candor, and selflessness. In addition, oral and written communication skills are not evaluated separately in EERS, as they are in OERS. Only "communication ability" is a ratable item, implying assessment of both verbal and writing skills.

Table 2 also lists several low job-related standards of evaluation that are found in these systems. For example, OERS and EERS explicitly require evaluation of an individual's military bearing or appearance and physical fitness. While some will certainly argue that both components are necessary prerequisites for being a "good" commissioned or noncommissioned officer, studies that can document the essential nature of these components to all Army jobs are lacking. For example, being physi- 
TABLE 2

Trait Evaluation Components of Army Military and Civilian Personnel Performance Appraisal Systems

\begin{tabular}{|c|c|c|c|}
\hline Locus of Evaluation Standards & OERS & EERS & CPAS \\
\hline \multicolumn{4}{|l|}{ High Job-Relatedness: } \\
\hline Task Knowledge/Skills/Expertise & $E$ & $E$ & $T$ \\
\hline Subordinate Development & $E$ & $E$ & $\mathrm{~T}$ \\
\hline Subordinate Motivation & $E$ & & $T$ \\
\hline Communication Ability - Written & $E$ & 1 & \\
\hline Communication Ability - Oral & $E$ & $E$ & \\
\hline Sound Judgment & $E$ & $E$ & \\
\hline Adaptable & $E$ & $E$ & \\
\hline Performance Under Stress & $E$ & $E$ & \\
\hline Equal Opportunity Support & $E$ & $E$ & $E(S)$ \\
\hline Seeks Self Improvement & $E$ & $E$ & I \\
\hline Conceptual Capacity & $E$ & & \\
\hline Initiative & & $E$ & \\
\hline Establish High Standards & $E$ & & \\
\hline Dedication & $E$ & & \\
\hline Responsibility & $E$ & & $T$ \\
\hline Loyalty & $E$ & $E$ & \\
\hline Discipline & $E$ & $E$ & \\
\hline Integrity & $E$ & $E$ & \\
\hline Moral Courage & $E$ & $E$ & \\
\hline Selflessness & $E$ & & \\
\hline Encourages Candor & $E$ & & \\
\hline \multicolumn{4}{|l|}{ Low-Job Relatedness: } \\
\hline Moral Standards & $E$ & & \\
\hline Military Bearing/Appearance & $E$ & $E$ & \\
\hline Physical Fitness & $E$ & $E$ & \\
\hline Lifestyle & 1 & 1 & \\
\hline
\end{tabular}

Notes: $\mathrm{E}$ - Explicit component of the appraisal

I- Implicit part of the appraisal

$E(S)$ - Explicit part of supervisory personnel appraisals

cally fit is important to a combat soldier who not only must maintain a "readiness posture," but also may participate in many field-related duties that have rigorous physical requirements. For such an individual this would seem to be a job-related requirement and would be appropriate in the evaluation. But can the same be said of years when he/she sits in an office, a supply room, or any other non-physically tasking position? Such a trait is not job-related during these periods and it is not jobrelated for persons who spend an entire career in assignments that have low-physical demands. This is the reason for classifying physical fitness in the low-job related category.

OERS also explicitly calls for evaluation of one's moral standards. This item is not only low in job-relatedness, but it is also an "objective" component that clearly has 
a subjective character to it. After all, who defines "moral standards" but the person rendering the evaluation - a definition that will vary from rater to rater. Finally, an implicit subjective evaluation item in both OERS and EERS is the "lifestyle" of the ratee. Although not required, many completed appraisals contain comments in the subjective performance section (see Table 3) that are related to lifestyle. Frankly, persons leading questionable lifestyles are unlikely to receive a favorable evaluation by their Army supervisor. Like moral standards, military bearing and appearance, individual lifestyles are microscopically observed throughout a commissioned or noncommissioned officer's tenure in a position.

CPAS does not explicitly call for any trait evaluations. Most of what is included in the appraisal are task-specific evaluation items. The appraisal must be conducted in relation to performance standards of quantity, quality, or timeliness of task accomplishment. The only way that any traits might be included in CPAS evaluations are in terms of specific tasks that call for that trait or value in the rated individual. For example, Table 2 shows that task knowledge/skills/expertise are ratable, but only in terms of specific tasks of major job elements. In addition, subordinate development/ motivation and responsibility may be evaluated if the rated individual's performance standards include such. The only trait, similar to that found in OERS and EERS, explicitly directed in CPAS is supporting equal opportunity programs (and this item is only evaluated for civilian supervisor-level positions).

One item that is implicit in the civilian employee performance appraisal is seeking self-improvement. Since the status of the previous IDP must be included, a supervisor may make what amounts to evaluation comments on the plan. Of course, it is possible for a supervisor to only treat "self-improvement" in terms of self-development activities, and therefore, should an ernployee not have any self-development plans, that factor could not be evaluated in any fashion. Finally, as Table 2 indicates, CPAS does not contain any explicit or implicit components that meet Nalbandian's definition of low job-relatedness. However, it is possible for such items to creep into the appraisal if a manager feels that one's lifestyle or moral standards have somehow affected task accomplishment.

The inclusion of traits in the evaluation of officers and enlisted personnel is another sign of the lack of maturity in the systems. Trait approaches and graphic rating scales have been under heavy criticism for years, particularly due to the poor validation results when job performance has been compared to trait appraisal (Klingner, 1980: 228-231; Greiner, 1981: 227-230). It allows Army managers to continue a "Theory X" philosophy in rating personnel.

\section{OBJECTIVE VS. SUBJECTIVE EVALUATIONS}

The third way that we may compare systems is on the use of objective (or performance-based) versus subjective evaluation information. Table 3 presents a summary of such components found in these three appraisal systems. The subjective comments that appear in both OERS and EERS are fairly general in content. There is no requirement for rating managers to reference subjective remarks to specific tasks or 
TABLE 3

Objective zs. Subjective Evaluation Components of Army Military and Civilian Personnel Performance Appraisal Systems

\begin{tabular}{lccc}
\hline Component & OERS & EERS & CPAS \\
\hline Subjective: & & & \\
General Performance Comments & E & E & \\
Potential Comments & E & E & \\
Potential - Comparative Cmmts & E & 1 & \\
Objective: & & & E \\
Task Performance Comments & I & E & E \\
Results-Oriented Comments & E &
\end{tabular}

Notes: $E$ - Explicit component of the appraisal

I - Implicitly part of the appraisal

assignments. Rather, the performance comments cover a range of areas that describe the character of the ratee as well as the nature of his/her performance. In contrast to this process, CPAS requires task-specific objective comments. These comments must be related to performance standards and the degree to which the ratee met such. As addressed earlier, although the task performance comments should assess the quality, quantity, or timeliness of meeting performance standards, the rating manager may include purely subjective remarks provided that these remarks are related to tasks. As indicated in Table 3, task performance comments are an implicit part of both OERS and EERS. That is, the general performance comments section allows the rater to be as specific about performance as desired. However, comments on specific tasks or assignments are not required in these systems.

One area of objective evaluation that is common across these systems is the focus on results. CPAS, with its reliance upon tasks and related performance standards, is necessarily a results-oriented system. Raters must comment on how successful the rated individual has been in meeting performance standards. OERS is also resultsoriented due to the inclusion of objectives planning at the start of the rating period. The rated officer must specify on the "support form" at the end of the rating period, the success that he/she has had in accomplishing established goals. The rater then considers this in rendering the appraisal and must indicate the "frequency" with which the ratee had attained results. ${ }^{4}$ Finally, EERS is also a results-oriented system, although to a lesser degree than the other systems. Raters must explicitly assess the rated individual's "professional competence" in "attain(ing) results" as a part of the trait portion of the appraisal. In addition, the rater may make comments on this in the general performance comments section of the appraisal form. ${ }^{5}$

Comments on potential of rated individuals are the last subjective items included in the systems, and clearly reflect the differences between rank-in-person versus rank-in-job foundation of military and civilian positions in the federal bureaucracy. ${ }^{6}$ In OERS and EERS, raters are required to assess the potential of individuals for future promotions or assignments of higher responsibility. In addition, both systems require that the potential of individuals be assessed in comparison to other individ- 
uals of similar rank or standing. This peer comparison places the rated individual in a subjective category based upon the rater's past experience in rating individuals of the same rank. The inclusion of this potential ranking makes sense for Army personnel since the military personnel system is organized into a rank-in-person system. Individuals are forever being considered for promotion to higher ranks. Not so in the civilian personnel system. CPAS does not include an assessment of individual potential for future promotions or assignments of higher responsibility because it is part of a rank-in-job personnel system. Individual competence is evaluated only in present positions since this is not a career system, like the military. Rather, individuals must qualify through personal achievements, or merit considerations, for future promotions. There is no obligation for managers to qualify employees for such, nor to even assume that individuals may desire to leave their present position.

\section{EVALUATING BY THE NUMBERS}

A last point of comparison serves to differentiate the three systems even further. Before the new OERS came into existence, officers were not only rated on objective and subjective components of an appraisal, but the objective components were assessed numerically. That is, various components were scored numerically and these scores were then summed to a maximum of 200 points. In many ways, despite the professed importance of subjective verbiage, the key factor for any ratee was the score. Because of the importance placed on the numbers, raters began to produce inflated scores that made the only possible scores very close to 200 . "Grade inflation" in the OER led to the implementation of the new OERS where traits are graphically scaled or rated but these are not summed to form any type of overall score for the officer. This was a needed improvement in the system.

EERS was also changed to correct some "grade inflation" problems of the old system. But in the process of changing factors of evaluation and items of appraisal, EERS policy-makers did not eliminate evaluation by the numbers. There are 10 "professional competence" traits that may be scored from 5 to 1 (high to low). These ten items may be summed to a maximum of 50 points. "Professional standards" includes seven traits, such as integrity, loyalty, and military appearance, with a similar scoring process, yielding a maximum score of 35 . Finally, potential is scored in one of three categories:

\author{
"Promote Ahead of Peers" \\ "Promote with Peers" \\ "Do Not Promote"
}

\section{$38-40$ possible points 20-37 possible points \\ 0-19 possible points}

This awkward scoring process for potential effectively removes some scores from consideration by rational raters. For example, if a rating manager is serious about wanting to see an individual considered for promotion ahead of peers, then the rational choice is 40 points, not 38 or 39 . Likewise if one does not wish to see an individual promoted, the rational choice is zero points, not 1 through 19 . But grade inflation remains a problem for this system so raters are pushed to award points to 
people who are not recommended for promotion or early promotion in the potential category. The summation of EERS scoring is 125 points (an average of both a rater and an indorser ${ }^{7}$ evaluating the individual). And, like other evaluation-by-the-numbers systems, the true assessment of an individual's worth comes in the score, not in the performance comments. This is a further representation of the immaturity in this system.

CPAS has no rating using numbers. As such, it is superior to both OERS and EERS. The enlisted evaluation system is clearly the worst system due to its reliance upon an inflated system of numbers.

\section{CONCLUSION}

This paper has compared the three performance appraisal systems used in personnel evaluation processes for officers, noncommissioned officers, and civilians. The most objective-based system is CPAS with its emphasis on performance standards rather than on trait measurement. Civilian employees know what their rater's expectations are and what must be done to be a "fully successful" employee. There are no low job-related factors explicitly included in the appraisal of civilian performance, nor are personnel rated "by-the-numbers." OERS is another objective-based system of personnel management, but it is not without problems. The maturity of the system is undermined by inclusion of trait evaluations and the opportunity to rate officers in the performance comments section on other-than-objective bases. In addition, OERS explicitly includes several low job-related factors in the evaluation. But like CPAS, this officer evaluation system is a positive step toward management-by-objectives in the officer personnel management arena.

The enlisted evaluation system is dominated by the management philosophy of "Theory X." It is clearly a less mature system than either the officer or civilian systems. EERS relies heavily on what Klingner (1980: 231-233) has called graphic rating scales and which I indicated lead to "evaluation-by-the-numbers." Enlisted personnel are not managed through performance objectives and standards. Heavy emphasis is placed on attaining a numerical score based upon trait evaluation of both high and low job-related standards or values. The existence of EERS makes the personnel management process very confusing and difficult for Army managers. This system emphasizes different approaches to personnel management of enlisted personnel than that used for officers or civilians.

Ignored in developing these systems was the close similarity between the duty assignments of these three classes of public employees. Military personnel and civilian personnel should be appraised using systems that foster similar values. In this respect, CPAS could become a model for reform of EERS. Army managers do not need the same instruments for appraising performance of the three groups. But what is needed is similarity in the values and approaches to performance appraisal for all three groups. A management-by-objectives process is clearly needed in enlisted personnel evaluations. Implementation of MBO would improve the management capa- 
bility of Army managers and put the military performance appraisal process on a similar basis with the civilian system.

\section{NOTES}

${ }^{1}$ Civil Service Reform Act, Title II, Public Law 95-454.

${ }^{2} \mathrm{~A}$ "critical" element, according to the Office of Personnel Management (1981: 58) is ". . usually a key responsibility or major duty, that is of sufficient importance that performance below the minimum standard established by management requires remedial action. . . and may be the basis for removing or reducing the grade level of that employee. Such action may be taken without regard to performance on other components of the job."

${ }^{3}$ According to OPM (1981: 58) a performance standard is defined as ". . an expressed measure of level of achievement. . .established by management for the duties and responsibilities of a position or group of positions.

${ }^{4}$ See Department of the Army Form 67-8 (U.S. Army Officer Evaluation Report), p. 2; and Department of the Army Form 68-8-1 (Officer Evaluation Report Support Form), parts II and III.

${ }^{5}$ See Department of the Army Form 2166-6, Enlisted Evaluation Report, part III, A\&C.

${ }^{6}$ For a discussion of the differences between rank-in-person and rank-in-job systems, see, for example, Cayer, 1980: 77-84; and Mosher, 1968: 147-175.

"The indorser is the second-line supervisor who functions as a "senior rater" in the system.

\section{REFERENCES}

Brown, Robert W. (1982). "Performance Appraisal: A Policy Implementation Analysis," Review of Public Personnel Administration 2 (Spring): 69-85.

Cayer, N. Joseph. (1980). Managing Human Resources (New York: St. Martin's Press).

Colvard, James E. (1982-83). "Performance, Pay, and Promises," The Bureaucrat 11 (Winter): 28-29.

DeMarco, John J. and Lloyd Nigro. (1983). "Implementing Performance Appraisal Reform in the United States Civil Service," Public Administration 61 (Spring): 45-57.

Department of the Army. (1979). Army Regulation 623-105, Officer Evaluation Reporting System. (1981a). Army Regulation 623-205, Enlisted Evaluation Reporting System. (1981b). Army Regulation 623-105, Officer Evaluation Reporting System.

Greiner, John M. (1981). Productivity and Motivation: A Review of State and Local Government Initiatives (Washington, D.C.: The Urban Institute).

Klingner, Donald E. (1980). Public Personnel Management (Englewood Cliffs, N.J.: PrenticeHall, Inc.).

McGregor, Douglas M. (1960). The Human Side of Enterprise, (New York: McGraw Hill). (1972). "An Uneasy Look at Performance Appraisal," Harvard Business Review 50 (September-October): 133-138.

Mosher, Frederick C. (1968). Democracy and the Public Service. (New York: Oxford University Press).

Nalbandian, John. (1981). "Performance Appraisal: If Only People Were Not Involved," Public Administration Review 41 (May/June): 392-396.

Office of Personnel Management. (1981). Manager's Handbook. (Washington, D.C.: Government Printing Office).

Sherwood, Frank P. (1982-83). "Wrong Assumptions, Wrong Strategies," The Bureaucrat 11 (Winter): 22-27.

Stevens, John E. (1980). “OERS: Management by Objectives," Military Review 60 (November): 9-13. 
Sugar, Mary M., Priscilla L. Levinson, and Charles H. Anderson. (1979). "Performance Appraisal-Cornerstone of Civil Service Reform," Civil Service Journal 19 (April/June): 19-20.

Thayer, Fred C. (1981). "Civil Service Reform and Performance Appraisal: A Policy Disaster," Public Personnel Management 10 (Spring): 20-28.

Thompson, Duane. (1981). "Performance Appraisal and the Civil Service Reform Act," Public Personnel Management 10 (Fall): 281-288.

\section{Resource Management Associates}

Personnel Studies • Executive Recruitment Assessment Centers • Classification and

Pay Plans • Productivity Improvement

\section{Gateway Centre}

20 South Route 45

Frankfort, lllinois 60423

(815) 469-3111

\section{COMPARABLE WORTH?}

Finally! A comprehensive six-factor (21 sub-factor) system to compare jobs point-by-point to prove sex discrimination (or disprove).

Price Includes

complete system, samples for comparison, full instructions. Copyrighted! $\$ 375.00$ complete.

$$
\begin{gathered}
\text { TCl, Inc. } \\
5419 \text { Wayman Lane } \\
\text { Salt Lake City, Utah } 84117 \\
\text { 801-278-6050 } \\
\text { (Theda L. Timmins, President) }
\end{gathered}
$$

Used in several states, many local governments, with thousands of employees.

STATISTICALLY VALIDATED WRITTEN TESTS

for Police Officer, Sergeant, Firefighter, Fire Lieutenant and Captain

Validation Report and Inspection Copy- $\$ 20.00$ each test

CONTENT VALIDATED TESTS FOR MOST MUNICIPAL OCCUPATIONS-

Based on job analysis and specifically tailored to fit your jobs.

We provide complete service, usually including norms, a passing point recommendation, defense service's and a Study Guide and book list for candidates.

ASSESSMENT CENTERS-ORAL EXAMINATIONS-

CLASSIFICATION AND PAY SURVEYS.

MCCANN ASSOCIATES, INC.

Consultants in Public Management Since 1959

2757 Philmont Ave., Huntingdon Valley, Pa. 19006, (215) 947-5775 


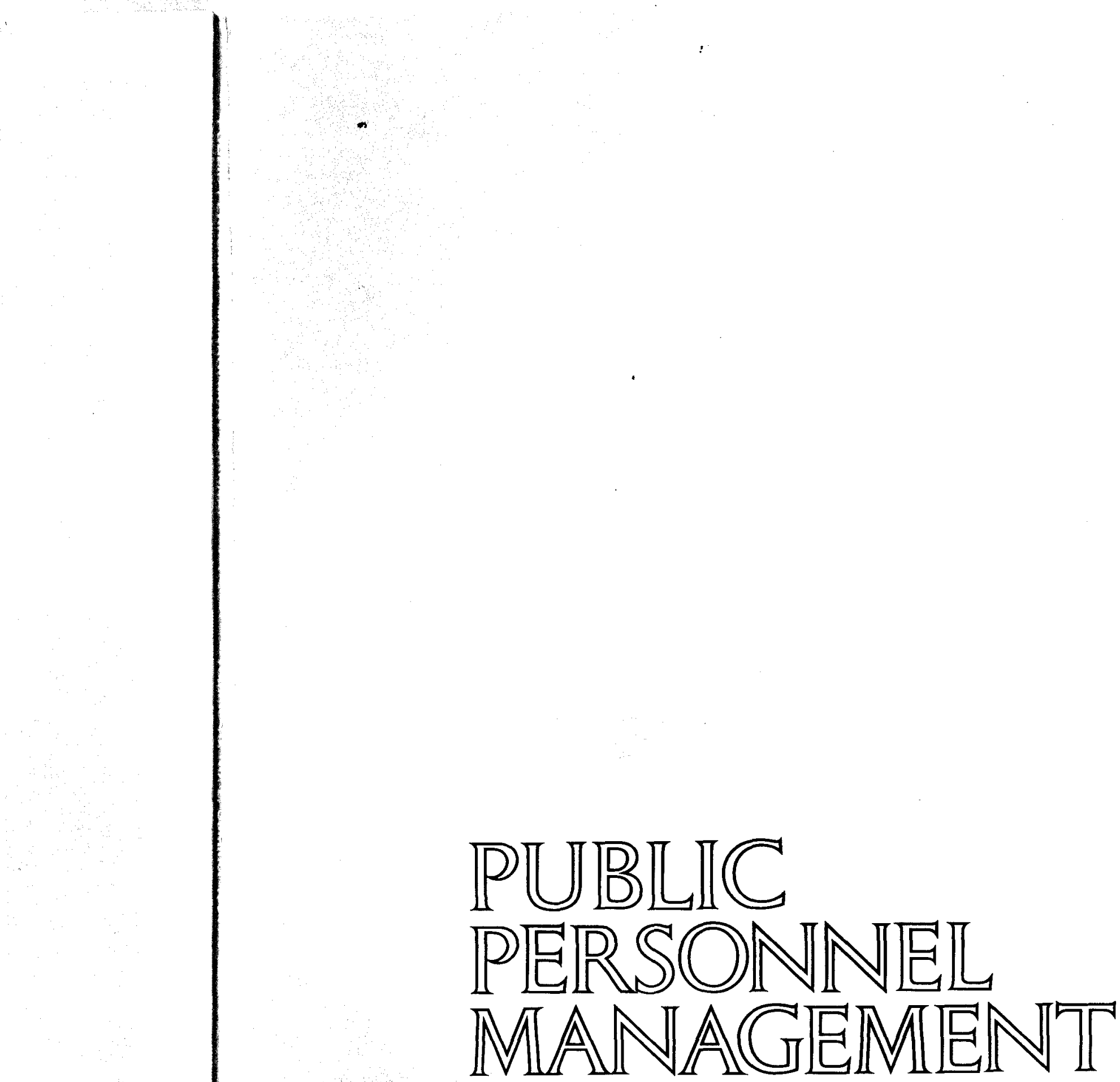

